\title{
Tesco in Korea: regulation and retail change ${ }^{1}$
}

\author{
Woohyoung Kim*, Alan George Hallsworth** \\ *Research Team for Commercial Districts Development, Agency for Traditional Market Administration, Small \\ Medium and Business Administration, Seoul, South Korea \\ **Portsmouth Business School, University of Portsmouth, Hampshire, UK. (Corresponding author. Email: \\ alan.hallsworth@port.ac.uk)
}

\begin{abstract}
In South Korea, rising resistance has slowed the advance of global retailer Tesco to the advantage of traditional shopping locations. In 2013, Tesco claimed that retrospectively-applied Korean Sunday trading regulations reduced its trading there by $8 \%$. We utilised secondary sources and also conducted an empirical survey of 1,092 consumers in 22 Korean cities to assess reactions to this regulatory change and found evidence of spatial switching back to traditional locations. Our Korean respondents supported the new Sunday trading restraint. Such an outcome would not be expected in those western countries where further liberalisation is still promoted. Also, the poor trading figures announced by Tesco-Homeplus in 2013 imply that Homeplus never fully adjusted to the Korean market. Issues of society and culture continue to challenge commercial innovations: with spatial implications.
\end{abstract}

Key Words: Retail internationalisation, Tesco, Sunday Trading, Korea

\section{INTRODUCTION}

In most advanced economies the food retail sector is a major employer but is also diverse and usually complex. As Hallsworth (2013 pp 275-6) observed "(food retail) can be approached from many academic perspectives (and) ...tends to be influenced by regional or national, social, regulatory or economic factors". Note that the latter influences were not a major feature of early attempts to devise ideal-typical spatial patterns for market-serving industries such as retailing. Despite such diverse contemporary influences, Wal-Mart, Carrefour and Tesco, the three largest global food retailers, prospered by developing remarkably similar store formats. Opening hypermarkets $^{2}$ enabled Tesco to grow substantially. In 1982 Tesco was not even the largest grocery retailer in the UK yet 30 years later was one of the global Big 3. However, in July, 2014, Chief Executive Philip Clarke resigned in the face of falling profits. A long-serving Tesco employee, he had been CEO for only 3 years but failed to turn corporate performance around. Worse still, by October, 2014, five Tesco executives had been suspended after it was revealed that profits may have been overstated. This reminded many observers of the problems at Ahold some years previously. A major setback for Tesco had been the failure of its venture in the USA which lost $£ 1$ billion. Ryle (2013 p 308) reported that Tesco had underestimated the

1 The authors would like to thank the editors and referees for their helpful and constructive comments.

${ }^{2}$ Also known as superstores, supercenters or, in Korea, Super-supermarkets (SSMs) 
effects of California's Labour laws. Fully understanding overseas markets is vital: especially when a third of Tesco profits derive from its overseas businesses. Indeed, there is a growing list of countries that the Big 3 in general have entered only to later leave. In Europe, one important regulatory factor is land-use planning or development control (Hallsworth and Evers, 2002, Evers 2004). In the UK, despite development controls, hypermarkets have continued to be opened: often despite vocal local protests. Accordingly, where regulatory features of 'host' countries have been receptive, research has more often focused on how consumers react to new retail choices. When, however, the largest food retailers locate in countries that are culturally and physically remote, unexpected forms of resistance may arise. The recent troubles of Carrefour as well as Tesco attest to this: in 2012 alone, Carrefour left several important markets including Brazil and China. Here we focus on Tesco's claims (see Tesco annual report 2013) that it was retrospective application of Sunday trading restrictions that caused the problems in Korea; a country that Wal-Mart and Carrefour had already entered and left (Kim and Jin 2001, Ramstad 2006, Kim 2008). This change contrasts strongly with Europe where, if trading hours regulations change, they tend to become more relaxed (Blomley 1985, CPB 1995, Grunhagen and Mittelstaedt 2001)

\section{RETAIL INTERNATIONALISATION}

In studying trends in South Korea, we cover retail internationalisation and especially the influence of government market regulations. Whilst it is popularly portrayed that government restrictions on retail firms are unpopular with shoppers, our sample did not reveal this to be so. Korean culture, as reflected in the symbolism of its national flag, embraces balance and harmony. It may be difficult to link retail policy to a love of harmony but retailers need to secure local acceptance and this, like harmony, takes time. Intriguingly, academic research on Tesco in Korea has already covered the topic of how it 'became local' and we explore this further. In South Korea, Coe and Lee (2006) noted: "work has thus far been preoccupied with market entry strategies and has looked less at what happens after(wards) ... Tesco's strategy in South Korea is best characterized as one of "strategic localization'" (Coe and Lee 2006; Coe and Lee, 2013 see also Suh and Howard, 2009). We accept localization as a key starting point for market acceptance but suggest that harmony is a long-term project. We will not further consider the well-researched field of generic motivations for internationalisation (Akehurst and Alexander 1996, Sternquist 1998, Dawson, 2001).

\section{THEORETICAL UNDERPINNINGS AND METHODOLOGY}

The seemingly-inexorable rise of the hypermarket, despite frequent local protests, attests to the power imbalance between firms such as Tesco and their weaker rivals. Power factors are outlined in the work of Stewart Clegg which covers influences from key individuals to global sea-changes in technology (Hallsworth 1997). Other literatures, too, explain how power imbalances become established. Davies (2010) has researched how pro-big-business Chicago-School theories on Competition Policy and Law have become dominant. Such attitudes hold that all activities, even anticompetitive ones, are the natural outcomes of rational profit-maximising decisions taken by big business and claim that consumer welfare is best served by short-term low prices. Businesses offering the latter have naturally thrived (Davies 2010). With many organisations such as the WTO, and DG MARKT in the EU, pushing for open borders and free trade the dominance of big transnational firms seems unstoppable. Indeed, Gagné (2011) gives examples where trade agreements have been structured to 
ensure that future democratically-elected governments cannot easily undo agreements favourable to big business. This leads to oligopolistic market structures and large firm dominance and Serpkenci and Tigert (2010 p61) have suggested that "there will be but just two retailers remaining in many product-market spaces in North America". For evidence of power abuses by dominant corporations see Consumers International (2012) and Berasategi (2014).

A further difficulty when studying power imbalances is that research often only examines one of the opposing perspectives - not both. Like Coe and Lee (2006) much literature on retail internationalisation takes the perspective of the powerful incoming retail chain. Resistance and failure are the obverse of compliance and success but are far less commonly covered. As Burt et al (2002, p. 193) put it: "The idea of failure in retail internationalisation hardly registers at all". However, resistance does occur and challenges the notion that retail internationalisation is inherently unproblematic. This is a manifestation of the opening up of 'free' markets for goods and services: a process that has long been driven by the WTO and others. The idea of reciprocity, accepting the products and services of those who accept them from you, is appealing. Retail choice, however, unlike product choice, is inherently locally-contingent and its local negativities are harder to ignore. Looking at sources of resistance, it is possible to identify several different manifestations. Key 'resisters' can include the general public and established retailers. Our studies suggest that smaller retailers tend to protest whilst larger rivals have the scale and scope to modify their trading to face the competitive threat.

The role of government is more difficult to predict. As revealed by Sparks (2008) and predicted by Clegg (1989) powerful global retailers do not just write letters of protest. They gain access to the highest levels of government specifically in the hope of having laws changed. Tesco itself offers a classic example. 50 years ago, Jack Cohen, founder of Tesco, personally lobbied Government for the abolition of Resale Price Maintenance in Britain (Ryle 2013). Smaller, weaker, retailers have much less political power - unless they band together to organize. A complicating factor is that of store format. IKEA had far less success in opening their huge, land-hungry, stores in densely-populated Britain than in their home territory of thinly-populated Sweden. Corporations running large format stores can, and do, accumulate great market and political power: but the intrusiveness and disruptiveness of their large stores can be a problem in itself. France, Belgium, Britain and Ireland are among many countries that have at times, placed size limitations on stores (or forced extra controls onto them). Korea's Sunday trading laws represent a hybrid in that it is not size per se but conglomerate ownership that is the criterion. The trend in recent years, however, has been to relax large store restrictions: one reason being that, having become politically powerful, operators of huge stores become much harder to resist. A further complicating factor arises if restrictive policies are imposed by one level of government but administered by another: especially if that administrative power is weak and fragmented in the face of the substantial financial power of big retailers.

Yet the exercise of power does generate resistance and we seek to identify the roots of rising resistance to Tesco in South Korea. A further factor that is relevant to Clegg's widest, facilitative Circuit of Power has been identified by Henderson (2011). To generalise, Henderson's four-fold typology outlines the relationship between the state and the national economy. Neoliberal economies such as the UK and USA contrast with Asian economies such as South Korea. Henderson (2011 p 42) positions the UK and Korea as polar opposites. So, political economy, too, is a key theoretical 
underpinning to power and resistance. We sought to capture empirical evidence of resistance by using mixed methods. Foremost, we conducted a survey to evaluate consumer behaviours and opinions after Korea's mandatory Sunday closure of large stores was retrospectively enforced. We interviewed consumers who had visited large discount stores such as Tesco Homeplus in South Korea. We examined consumer awareness of the mandatory closures and asked questions relating to changes in shopping behaviour: in essence, the long-established Impact Study approach (e.g. Timmermans 1979).We also studied newspaper accounts and written evidence of other contemporary forms of resistance - including street protests. Our intention was to outline how local resistance to Tesco later grew once Homeplus had become a power in Korean retailing. We examined which groups and individuals in Korea sought to resist Tesco Homeplus. Research on personal, less organized, resistance or anti-choice also offers helpful theoretical underpinning (Hogg and Michell 1996, Hogg 1998). Ram and Sheth (1989, p.6) suggest that "resistance (is) offered by [individuals] to an innovation, either because it poses potential changes from a satisfactory status-quo or because it conflicts with their belief structure." In Korea, the underlying belief structure is commonly characterised as interpersonal harmony. Evidence has emerged that Homeplus, whilst generally seeking to be Korean in outlook, sometimes behaved in ways that were bound to attract opposition. This is despite the fact that Tesco's market entry strategy was intentionally localized. Key to this was one individual of whom Coe and Lee (2006, p.77) wrote: “... Lee SeungHan ... CEO of Samsung-Tesco ... has made great efforts to create a "glocalized" corporate culture". We, however, found that Homeplus under Lee Seung-Han, who left in February 2013, after 16 years (The Korea Times 2013), did not exclusively seek to minimize the likelihood of resistance. Despite not using the name Tesco and preferring Homeplus, Tesco later generated opposition from incumbent retailers and from policymakers. Furthermore, the other powerful existing multiples in South Korea 'upped their game' and fought back. Together, Homeplus and its largest rivals have taken trade from traditional 'embedded', formats. Resistance from that sector, too, became stronger and has come in two ways that we go on to illustrate. The main one is lobbying for certain forms of market protection. The other is emergent and very public resistance to particular Tesco proposals (below). These included objections to statements made by Lee Seung-Han himself.

\section{THE KOREAN RETAIL INDUSTRY}

Once its economy opened up to overseas investment the retail industry in Korea rapidly restructured (Kim and Hallsworth 2013). Small business owners and traditional markets lost market share whilst large discount stores and Supersupermarkets (SSMs) gained it. The Small and Medium Business Administration (SMBA 2010), reported that there were 1,517 traditional markets, 200,000 stores, and 360,000 merchants in 2010. However, 143 traditional markets, 39,000 stores, and 23,000 merchants had ceased operations since 2005. Table 1 illustrates that the revenues and numbers of new store formats (large discount stores, SSMs, convenience stores, and non-store retailing) are consistently on the rise. As elsewhere, the growth of large discount stores has faltered in recent years: inviting us to update the work of Suh and Howard (2009). For example, large Korean discount stores achieved KRW 28,400 trillion in sales revenue and at least $10 \%$ growth in 2007 . However, the growth rate decreased to $3.6 \%$ in 2009 and, as a result of restructuring beginning in the mid2000s, large discount stores were consolidated into a Korean 'Big 3' (E-mart, 
Homeplus, and Lotte-Mart). Between them the Big 3 hold a market share of approximately $80.5 \%$ ).

\section{RISING SOCIAL OPPOSITION AND SUNDAY TRADING RESTRICTIONS}

Before revising their Sunday Trading policies (see The Korea Times 2012), the Korean government earlier enacted the "SSM Restriction Law" to limit the SSM's hitherto-uncontrolled expansion into the geographical sphere of small businesses. This was a policy with a clear spatial expression - banning new enterprises in established retail areas (as described by Kim and Hallsworth 2013). Possibly uniquely, the 2012 Sunday trading law then retrospectively applied Sunday opening laws to existing conglomerate-owned retail stores. According to an SMBA press release (2012), 341 out of 436 large discount stores (78\%) and 828 out of 1,124 SSMs (73.6\%) implemented mandatory shutdowns on the second and fourth Sundays of each month in accordance with the SSM Sunday trading Restriction Law. This is a particularly interesting development since many countries that once enacted Sunday trading restrictions, usually on religious, moral or social grounds, have since seen them eroded or removed (Richter 1994, Kennedy 2010). Unusually, Korea restricted an existing right to trade on Sundays in a way that explicitly targeted certain types of large companies. The UK press reported (e.g. The Telegraph 2012) that Tesco found this affected their trading in Korea (see Tesco 2013). This re-focused research on both Sunday trading and the control of trading hours in general. Writing about Germany, Kirby (1992) noted that "the Store Closing Law of 1956 (was) opposed by the large firms since they were seen as favouring the small trader. Over the years, however, the town centre department stores and supermarkets have become major supporters of the regulations. The Store Closing Law (is) maintaining the importance of both the town centre and the department store in the retail system." (Kirby 1992, p.228-9). This suggests that, if there are spatial implications, we should expect that trading hours restrictions can benefit existing retailers in traditional locations. Incidentally, in 2004, Kaufhof AG took to the German Supreme Court the claim that the shop-closing law was unconstitutional: but the action failed. The Court stressed that Germany had a tradition of protecting Sundays and public holidays as days of rest and recuperation. Uncertainty has been introduced by the fact that it is not the Federal parliament but the states (Länder) that now regulate hours. Accordingly, it will be interesting to see if Korean retailers react like German ones and ultimately take advantage of the trading hours rules or like UK ones where most continue to campaign against them. 
$<$ Table-1> Retail Business in Korea

(Sales Unit: trillion Korean Won)

\begin{tabular}{|c|c|c|c|c|c|c|c|c|c|}
\hline & & 1996 & 2003 & 2005 & 2006 & 2007 & 2008 & 2009 & 2010 \\
\hline \multirow{2}{*}{$\begin{array}{l}\text { Traditional } \\
\text { Market }\end{array}$} & Sales & & 36.0 & 32.7 & 29.8 & 26.7 & 25.9 & 24.7 & 24.0 \\
\hline & $\begin{array}{l}\text { No. of } \\
\text { Markets }\end{array}$ & - & $\begin{array}{l}1,69 \\
5\end{array}$ & $\begin{array}{l}1,66 \\
0\end{array}$ & $\begin{array}{l}1,61 \\
0\end{array}$ & 1,610 & 1,550 & 1,550 & $\begin{array}{l}1,51 \\
7\end{array}$ \\
\hline \multirow{2}{*}{$\begin{array}{l}\text { Large } \\
\text { Discount } \\
\text { Store }\end{array}$} & Sales & & 19.6 & 23.7 & 25.7 & 28.3 & 30.1 & 31.2 & 33.7 \\
\hline & $\begin{array}{l}\text { No. of } \\
\text { Businesse } \\
\mathrm{s}\end{array}$ & 28 & 265 & - & 357 & 375 & 424 & 442 & 439 \\
\hline \multirow[b]{2}{*}{$\begin{array}{l}\text { Department } \\
\text { Store }\end{array}$} & Sales & - & 17.5 & 17.4 & 18.4 & 19.0 & 19.7 & 21.5 & 24.3 \\
\hline & $\begin{array}{l}\text { No. of } \\
\text { Businesse } \\
\mathrm{s}\end{array}$ & 109 & 85 & - & 83 & 84 & 82 & 83 & 83 \\
\hline \multirow{2}{*}{$\begin{array}{l}\text { Super- } \\
\text { Supermarke } \\
\text { t (SSM) }\end{array}$} & Sales & - & 18.4 & 18.6 & 19.3 & 19.5 & 21.5 & 22.4 & 23.8 \\
\hline & $\begin{array}{l}\text { No. of } \\
\text { Businesse } \\
\mathrm{s}\end{array}$ & - & 234 & 267 & 292 & 354 & 446 & 660 & 866 \\
\hline \multirow[b]{2}{*}{$\begin{array}{l}\text { Convenienc } \\
\text { e Store }\end{array}$} & Sales & - & 3.2 & 3.9 & 4.2 & 4.7 & 5.5 & 6.2 & 7.3 \\
\hline & $\begin{array}{l}\text { No. of } \\
\text { Businesse } \\
\mathrm{s}\end{array}$ & $\begin{array}{l}1,88 \\
5\end{array}$ & - & - & $\begin{array}{l}9,84 \\
7\end{array}$ & $\begin{array}{l}11,91 \\
7\end{array}$ & $\begin{array}{l}13,60 \\
9\end{array}$ & $\begin{array}{l}15,07 \\
1\end{array}$ & \\
\hline $\begin{array}{l}\text { Non-store } \\
\text { Retailing }\end{array}$ & Sales & 0.3 & 15.2 & 17.7 & 19.6 & 21.2 & 23.9 & 27.1 & 31.1 \\
\hline
\end{tabular}

Source: Korea Statistics (2011), SMBA (2011), Korea Chain Stores Association (2011). (Non-store retailing includes online sales, TV home shopping, etc.)

\section{TESCO IN KOREA}

Tesco-Homeplus entered the Korean market in 1995 and soon thrived. By 2011, Tesco Homeplus had achieved KRW 10,700 trillion in sales and had opened 127 stores, becoming the second largest retailer in Korea. Tesco Homeplus is the only foreignaffiliated company to achieve such success in the large discount sector. It did so, however, in ways that would be unfamiliar to its UK customers and to most in Western Europe. Homeplus became 'local' by devoting space to schools and even hospitals. Such 'social' developments attracted Korean customers who were seeking products at reasonable prices but who also wished to continue to shop with retailers explicitly demonstrating socially-harmonious behaviours. Homeplus contributed to the development of culture and art in the local community and, in a move that had no parallels with Tesco operations in the UK, opened 110 schools nationwide, with annual enrolment of 1 million members. In addition, Homeplus offers 6,000 instructors and professional courses (400 courses per store) annually (Homeplus.co.kr - see Homeplus 2012 for sustainability initiatives).

Despite these efforts, Homeplus began to court controversy by resisting regulations imposed by government. In Korea, such attitudes are readily construed as infringing 
socially-harmonious behaviour. Our press-based research discovered, for example, that CVS Homeplus evades the "Traditional Market Protection Zone" enacted in 2011, which limits the entry of corporate-controlled discount stores and SSMs within $1 \mathrm{~km}$ of the boundary of traditional markets. This is because Homeplus' ownership of CVS Homeplus was deliberately limited to $49 \%$ or less: thereby evading the regulation. Similar ownership modifications apply to 365plus in Daechi, Seoul which is a directly managed model store opened to recruit franchisees after Homeplus' decision to enter the convenience store franchising business. So, from very promising beginnings, Homeplus began to drift from its self-portrayal as an authentically Korean concern and this generated resistance.

\section{RESISTANCE TO TESCO IN KOREA}

To explore and measure resistance, we analyzed internal government documents and newspaper articles, and investigated one particularly high profile conflict. Regarding the latter, in 2011, when Korea-EU Trade negotiations were in progress, the Korean government received a letter from the EU negotiator. Tesco's head office in Britain had conveyed its concerns on the enactment of the Korean SSM restriction law to the Korean Ministry of Foreign Affairs and Trade. The Korean media inferred that the head office of Homeplus (Tesco, UK) was placing diplomatic pressure on the Korean government. Such un-Korean behaviour promptly inspired resistance from small-to mid-sized business owners and some progressive parties. The Korea Federation of Retailers, National Network of Saving Small-to Mid-sized Merchants, Korea Alliance of Progressive Movements, Democratic Labour Party, and People's Solidarity for Participatory Democracy held a press conference in front of the British Embassy and in May 2011 sent a letter of complaint. They asserted that Tesco Homeplus was not only indiscriminately expanding stores but also attempting to prevent the passing of the SSM restriction bill by lobbying the Korean political community and the British government. If Tesco had hoped to forestall the legislation they did not succeed: quite the reverse.

The letter from Tesco HQ not only sensitised even more Koreans to Homeplus' UK roots but brought an organized response from leading representative groups in Korea. It was also evident from press reports that earlier, more localized, un-co-ordinated and spontaneous resistance had taken place at several Tesco-Homeplus developments in the past. In May 2009, Homeplus began a 24-hour service at Cheongju City, ignoring requests by local residents not to do so. On the other hand, Korea's truly local SSM companies, such as E-mart everyday and Lotte Super, generally reflected public opinion and adhered to government policies. When Homeplus Express publicly expressed its discontent with government policies, it made itself the obvious target for protest. Examination of various sources including newspaper reports indicates growing resistance toward Homeplus from as early as 2005. Homeplus persistently opposed government policies and continued to expand its stores by avoiding regulations (e.g.: by changing ownership structures). We surmise that, from around 2005, Homeplus began to conduct its business with less consideration for local public opinion. Resistance, however, does not mean that change can always be stopped. For example, Homeplus attempted to open a store in Jinju City through an agency which justified the opening of the store by stating that they would invest KRW 80 trillion in the region and that KRW 3 trillion would be secured as tax income. Jinju City admitted that "it could not refrain from granting permission unless there was a flaw in the licensing procedure." This again stresses that procedures for store approval may be insufficiently watertight or mindful of local opinion. Accordingly, in an attempt to block the opening of the store, civic groups and 600 merchants from traditional 
markets staged a demonstration in front of Jinju City Hall. In 2009, local civic groups and small- and mid-sized business owners rallied to oppose the opening of a Homeplus Express in Wae-dong, Gimhae City in Gyeongnam. In our Gimhae and Jinju City examples, concerned locals stressed wider social and economic problems. Planning permission procedures, however, too often focus on legalities linked to the site and are inadequate to address such wider social concerns. Cultural factors are, in effect, written-out of formal processes - as in Britain where both the Competition Authorities and Local Planning committees disregard arguments based on moral imperatives or on social justice. Outcomes are usually won by those who can afford the best information. Unquantifiable or hard-to-measure effects such as the problems encountered by Wal-Mart in Argentina and Quebec should not however, be disregarded (see also Bianci 2008 on Chile).

\section{EMPIRICAL RESEARCH FINDINGS}

We conducted a survey in order to examine several aspects of the Korean Sunday trading changes. We assessed consumer awareness of the effect of mandatory closures for large discount stores and SSMs by the government of South Korea. We also sought customer opinions, positive or negative, and we looked to ascertain which trading locations, if any, benefited. Using structured questionnaires in 22 cities and 2 guns across Korea, we undertook individual interviews with consumers who had experience of shopping at large discount stores. Sample size was proportional to population and ran from May 10 to May 29, 2013, with a final sample of 1,092 respondents. The survey was carried out by a professional research company. The main content of the survey included individual opinions on the government's regulations after they were enacted and changes in consumption behaviour before and after the regulations were enforced.

Inevitably, shoppers at large stores do not reflect the total spectrum of society since children and certain other groups are not represented. To indicate the range of individuals who met our criterion of having recently experienced large store shopping we list the following characteristics. Slightly more than half the respondents were in their 40s and 50s and the number of married respondents was overwhelmingly more than single respondents. Also, more than half of the respondents came from households with at least 3 family members whilst $40.1 \%$ of the respondents were college graduates, and a majority of the households owned a car. $80 \%$ of the respondents had resided the current region for at least 5 years. The occupation of the respondents was, in order: owner-operator $(29.6 \%)$, housewife $(23.1 \%)$, office worker $(13.9 \%)$, service sector worker $(13.3 \%)$ etc., the average household income was in the order of KRW 3-4 million (27.0\%), KRW 2-3 million (23.7\%), KRW 4-5 million $(20.5 \%)$.

We first inquired about regulatory measures on large discount stores and SSMs. A majority of respondents (54.1\%) stated that the current level of regulations was appropriate, whilst $19.1 \%$ of respondents replied that the regulations should be further tightened. This finding, supportive of balance and harmony, is interesting. Most 'western' nations would surely resist any reversal of prior market liberalization. Yet in Korea the notion that regulations should be loosened again attracted only $12.0 \%$ support and the view that the regulations should neither be tightened nor loosened was supported by $19.1 \%$. Consumers broadly favoured mandatory Sunday closures for large discount stores. Indeed, when we asked consumer opinions on the possible prolongation of the regulatory act on large discount stores, those favouring prolongation $(61.5 \%)$ outnumbered those opposing it (10.4\%). Next, we looked into 
the frequency of shopping at large discount stores after the regulations were enacted. Respondents shopped $11.6 \%$ more at traditional markets but shopped $9.0 \%$ less at large discount stores. There were no significant changes in the frequency of shopping at department stores, SSMs, small-sized neighbourhood supermarkets, distribution specialty stores, etc. Customers shopped more frequently at small to mid-sized retail outlets (traditional markets + small to mid-sized supermarkets $=15.5 \%$ ) after the regulations were enforced. We also detected a change in amounts purchased before and after the regulations were enforced. Customers decreased their purchasing at large discount stores by $10.6 \%$, but increased their purchases at traditional markets by $11.7 \%$ and at small to mid-sized supermarkets by $2.6 \%$. A study, conducted by the administration and the Small Enterprise Development Agency, also suggested the number of customers was up $8.7 \%$ percent (Korea Joongang Daily, 2013a).

When large discount stores were forced to close twice a month, consumers purchased additional small quantities at local traditional markets and small to midsized supermarkets. We can only infer that decreased sales at large discount stores [due to the regulatory measures] were converted into increased sales at traditional markets and small to mid-sized supermarkets. Broadly, the Sunday trading outcome seems to lead to more 'traditional' shopping. Confirmatory results were presented at the conference for '2013 Agrifood Consumer Trends'. The researcher, Joo (2013) examined consumer consumption behaviour changes after the regulatory changes using 2010-2012 consumer panel data generated by Korea's Rural development administration. Financial results showed that consumer purchasing decreased by an average about 18,000 Korean won. Yet again, the decline in sales at large discount stores was, apparently, converted into business for traditional markets.

Next we asked our respondents about the 'losers' in this process: changes in monthly average visits to large discount stores by brand, (E-Mart, Homeplus, LotteMart), changes in satisfaction, and changes in average purchasing amount per visit, before and after the regulations were enacted. An analysis of the results revealed that monthly average visits decreased for all large discount store brands, by 0.3 visits to Homeplus, 0.2 visits to E-Mart, and 0.1 visits to Lotte-Mart. As for changes in satisfaction, satisfaction levels decreased by 0.04 - for Homeplus only - after the regulations were enacted. Conversely, satisfaction levels increased by 0.02 for EMart, and there was no change in satisfaction level for Lotte-Mart. Regarding changes in the average purchasing amount per visit, this dropped at all large discount stores. The decrease in purchasing amount was largest for Homeplus at KRW 17,470, followed by E-mart at KRW 7,776, and Lotte-Mart at KRW 1,915. We confirmed that Homeplus, Lotte-Mart, and E-Mart generated negative results for the first time, with revenue down 4.4 percent, 2 percent, and 9.5 percent in 2011 (Korea Joongang Daily, 2013b).

Finally, we questioned consumers about synergy between large retailers and small merchants - a topic referred to locally as win-win co-operation. The concept of cooperation rather than confrontation is a familiar one in Korea as demonstrated by a 2013 study by the Commission on Shared Growth (CSG 2013). On a scale of 1 to 5, the response that synergy between large discount stores and traditional markets is necessary was the highest at 3.54, followed by the response that synergy is helpful for the strengthening the competitiveness of traditional markets (3.22), the response that synergy is helpful for strengthening the competitiveness of large discount stores (3.12), and the response that synergy is actively underway (2.73). Examples of such retail cooperation soon began in some areas. Geumchon traditional market merchants 
arranged with a large retailer for them to receive service training from employees of its large discount store (Korea Joongang Daily, 2013b).

\section{FAVOURABLE REACTION TO SUNDAY RESTRICTIONS}

Two aspects of our consumer survey results stand out. First, of the three largest discount stores, Homeplus displayed the most prominent drop as indicated by monthly average visits by consumers, by satisfaction level, and by purchasing amount. Because Homeplus lobbied against Sunday trading closures they may have tarnished their corporate image. We did not cover this explicitly but the above three responses certainly imply that those consumers who were disappointed by the behaviour of the company may have deserted Homeplus. Secondly, we note that respondents who favoured the restrictions on large discount stores and SSMs outnumbered those who opposed them. Indeed, many respondents support prolonging the regulations beyond the planned end date of December, 2015. Korean consumers apparently believe that regulations against large discount stores help re-invigorate small and mid-sized retail channels: including traditional markets. The issue of retail regulation has always defied easy generalisation. In Britain, the first such laws are 800 years old (King Henry 11l) and covered goods sold by butchers and bakers with the purpose of deterring and punishing rogue traders. Another, more controversial, influence has been religion - Sunday trading offends some religious sensibilities. As Kirby (1992) noted, the effect of historic Sunday trading rules has been to favour small local shops. The need for small amounts of food and drink continues 7 days a week and small shops selling such products have mostly been exempt. The last 30 years, however, has seen a worldwide loosening of such regulations and so the Korean policy is remarkable. Elsewhere, some countries resisted large stores longer than others - in Europe, Italy is a good example. In others, large global firms arrived, but did not stay, as with Carrefour and Wal-Mart in Korea and Wal-Mart in Germany. A useful dichotomy may be that between the resisters and the capitulators.

Meanwhile, Korea, essentially for none of the classical reasons, chose to rein back large stores by using Sunday trading rules. What, then, really underpins our findings that shoppers switched to other outlets when store closures were enforced? Are Koreans reverting to past habits? Bear in mind that Tesco now has a large market share and many rivals have closed and so the status quo is gone as is the traditional pattern of local shopping. So, when people shop more at local, traditional, retailers because larger shops are closed on alternate Sundays, is this a sign of 'Korean culture' or is it simply because they are barred from shopping at those larger stores? Two separate forces may be at play. The controversy caused by Tesco in 2011 which ignited opposition (plus the closures among smaller, traditional stores) may have spurred the Korean authorities to respond. They did so by tightening Sunday trading, a restriction that, for example, Britain, would never consider making. Yet in Korea it gained public approval: an indication of Korean preferences for harmony and rebalancing. Indeed E-mart and Lotte-Mart, at least publicly, accepted the same regulations that Homeplus challenged. Also, co-ordinated local protest by incumbent Korean retailers helped to drive the change. At different times (as with the Poujadist movement in France) protest against the rise of larger, non-local rivals has gained popular support. This is not now evident in any organised way in Europe where even EU rules work against pro-local sentiments. It may therefore be that anti-Homeplus protests really are a sign of 'Korean culture' as well as the everywhere-evident hope of small local businesses that they will not lose further market share 
The effect of large stores on the national economy is a contested topic: (Haffner and Van Bergeijk (1997). According to international organizations such as the OECD, restraints on hypermarkets enforced in developed countries in the 1980s and 1990s had a negative economic effect. Somewhat predictably, the OECD (2001) pointed out that excessive restriction policies covering the distribution industry, including restrictions on opening hours, have a negative effect on the creation of added value and employment. Similar arguments, usually focused on achieving short-term low prices and on prioritizing scale efficiencies over local demands and preferences, reflect Chicago-School, neo-liberal arguments. Looking at French government restrictions on large discount stores in 1975-1998, Bertrand and Kramarz (2002) conducted an estimation of economic effects, and claimed that employment would have increased by $20 \%$ in the distribution industry had the restriction not been enforced. Purely economistic arguments always offer an apparently compelling case for the development of more and more hypermarkets: however, post-2008, the format has seen more difficult trading times in much of Europe. Such criteria inevitably ignore the particular social role of shops and shopping (Miller 1998). By including factors such as local cultural norms (as suggested by Henderson 2011) we have identified non-economic factors that transnational corporations (TNCs) such as Tesco may face in the future

\section{CONCLUSIONS AND FUTURE RESEARCH}

We examined some longer-term aspects of the entry of Tesco-Homeplus into the Korean market. Unlike Wal-Mart and Carrefour, which withdrew from the Korean market, Homeplus improved its internal competitiveness and achieved rapid growth. The factors which made Homeplus' growth possible included its localization efforts (apparently becoming Korean) its differentiated marketing strategy, its schools and its hospitals. However, from 2005 onwards -just as its rivals were leaving the country Homeplus opposed restrictions on the expansion of its large discount stores. It then met with conflict from the Korean government, small-and mid-sized business owners, and civic groups. Our survey analysed what Korean consumers thought of mandatory Sunday closures and found culturally-influenced opinions and growing consumer awareness that, despite its Samsung links, Tesco was not authentically Korean in nature. We demonstrated that consumers have become accustomed to the Sunday closures and that many would prefer to extend the regulations beyond 2015. We cannot, however, directly infer from our survey that this remarkable finding flows directly from concerns that Korean preferences for harmony had been undermined by certain actions and statements from Homeplus. What we do suggest is that for Tesco to ascribe its Korean trading problems solely to the new Sunday Trading laws does not give the full picture. It may even be that slippage in its image as a Korean business - as a result of controversial comments and actions, gave rise to pressure for government action. Tesco may, in part, have brought the Sunday trading problems upon itself. However, our questioning only revealed the changes, not the motivations behind them. Future research could use focus groups to reveal underlying motivations behind why Korean shoppers reacted as they did. That said, deep cultural attitudes may be taken for granted and rarely revealed without explicit prompting. It would surely be an even greater future challenge to discover why Homeplus felt it could afford to be more confrontational and less 'local' in outlook from 2005 onwards.

Based on our survey findings, we can tentatively suggest that there has been spatial switching away from locations favoured by SSMs such as Tesco and back to traditional shopping areas. Unfortunately, Korean beliefs in co-operation versus 
confrontation are remarkably difficult to quantify: which may also be why Wal-Mart and Carrefour apparently failed to anticipate them. An interesting factor is the very existence of the CSG and its concept of a "win-win growth index" (CSG 2013) which showed that Homeplus scored lowest when compared with rival conglomerates. This suggests that Homeplus should genuinely seek to cooperate with, rather than oppose, future government regulations in Korea. Of the large store operators, Homeplus was the one seen to be most seriously at odds with the government - with their former CEO leading the way. As archetypal Korean companies, E-mart and Lotte-Mart more positively adhered to proposals from government and local small- and mid-sized business owners and refrained from actively opposing restrictions on large discount stores, choosing, instead, to consider local opinion. On first entry, Tesco partnered with Samsung: a prudent strategy that was successful until the trading figures released in 2013. Now that more and more ordinary Koreans are aware of the Tesco link, genuinely pro-local behaviours are needed. Interestingly, in 2006, Sir Terry Leahy, then CEO, added the principle of local community to a Tesco "Corporate Steering Wheel", which already included finance, human resources, and operations. Thus, the policy of contributing to the local community was recognized by Tesco domestically and quite possibly because of initial learning from Korea. Why, then, did Homeplus not pursue that policy consistently in Korea itself to the benefit of traders in traditional shopping locations? It is precisely because non-economic factors too often go unheeded that further research is needed on their power to resist the dominance of vast transnational corporations. 


\section{References}

AKEHURST G and ALEXANDER N (1996) The internationalisation of retailing. Frank Cass, London.

BERASATEGI J (2014) SUPERMARKET POWER: SERVING CONSUMERS OR HARMING COMPETITION? Javier Berasategi www.supermarketpower.eu

BERTRAND, M. and F. KRAMARZ, (2002), Does Entry Regulation Hinder Job Creation? Evidence from the French Retail Industry, The Quarterly Journal of Economics, 117 pp 1369-1413.

BIANCI, C., (2008). Retail internationalization from emerging markets: Case study evidence from Chile. International Marketing Review, 26, pp 221-243.

BLOMLEY N (1985) The shops Act 1950. AREA, 17, pp25-33.

BURT S, MELLAHI, K, JACKSON T and SPARKS, L (2002) Retail internationalisation and retail failure International Review of Retail, Distribution and consumer research 12 pp191-219

CENTRAAL PLANBUREAU (CPB) (1995), "Economische effecten van liberalisering van winkeltijden in Nederland" (The Economic Effects of Liberalized Shop Opening Hours in the Netherlands), Working Paper, No. 74, The Hague.

CLEGG S (1989) Frameworks of Power. London: Sage.

COE N M and LEE Y-S (2006), The Strategic Localization of Transnational Retailers: The Case of Samsung-Tesco in South Korea, Economic Geography, 82 pp 61-88.

COE N M and LEE Y-S (2013), 'We've learnt how to be local': the deepening territorial embeddedness of Samsung-Tesco in South Korea, Journal of Economic Geography, 13, pp.327-356.

COMMISSION on SHARED GROWTH for Large Corporations and Small and Medium Enterprises (2013) CSG press release Korea, 27 May 2013

CONSUMERS INTERNATIONAL (2012) The relationship between supermarkets and suppliers: What are the implications for consumers?, July 2012

DAVIES W (2010) Economics and the nonsense of law. Economy and Society $39 \mathrm{pp}$ 64-83

DAWSON J (2001) Strategy and opportunism in European Retail Internationalisation . British Academy of Management 12 pp 253-266

EVERS D V H (2004) Building for consumption Academisch Proefschrift, Universiteit van Amsterdam: The Netherlands.

GAGNE, G., (2011)"The U.S. Policy on the Protection of Foreign Investment: From the NAFTA to the U.S.-Korea FTA", The Journal of World Investment \& Trade, 12 pp. 807-825.

GRUNHAGEN M and MITTELSTAEDT R A (2001) The impact of store hours and redistributive income effects on the retail industry. The International Review of Retail, Distribution and Consumer Research 11 pp 49-62

HAFFNER, C.G. and VAN BERGEIJK P.A.G. (1997), "Regulatory reform in the Netherlands - Macroeconomic consequences and industry effects", Directie Martwerking, Ministerie va Economische Zaken.

HALLSWORTH A G (1997) "Rethinking Retail theory: Circuits of Power as in integrative paradigm"_Geographical Analysis 29 pp 329-338

HALLSWORTH A G (2013) Food retailing Chapter 15 in The Handbook of Food Research (eds Murcott, Belasco, Jackson) Bloomsbury: London 
HALLSWORTH A G and EVERS D V H (2002) "The steady advance of Wal-Mart across Europe and changing government attitudes towards planning and competition", Environment and Planning C, 20 pp 297-310

HENDERSON J (2011) East Asian Transformation: On the Political Economy of Dynamism, Governance and Crisis. London: Routledge.

HOMEPLUS (2011-2012) website, (Homeplus.co.kr http://www.homeplus.co.kr/)

HOMEPLUS Sustainability Report (2012), Homeplus's CSR Team 2011/2012

HOGG, M.K (1998) Anti-constellations: exploring the impact of negation on consumption. Journal of Marketing Management, 14, pp133-58.

HOGG, M K, MICHELL P, (1996) Identity, self and consumption: A conceptual framework. Journal of Marketing Management 12 pp 629-644

JOO H (2013), consumer purchasing behaviours changes due to regulations on large retailers, paper presented to 2010-2012 Agrifood consumer trends conference (in Korean).

KENNEDY A-M, (2010), The history of New Zealand shop trading hours, International Journal of Retail \& Distribution Management, 38 pp. 625-640.

KIM, R B (2008) Wal-Mart Korea: Challenges of Entering a Foreign Market, Journal of Asia-Pacific Business, 9 pp 344-357.

KIM, J-O., and B. JIN (2001), Korean consumers' patronage of discount stores: domestic vs multinational discount store shoppers' profiles. Journal of Consumer Marketing 18 pp 236-55.

KIM W \& HALLSWORTH, A G (2013), Large format stores and the introduction of new regulatory controls in South Korea, The International Review of Retail, Distribution and Consumer Research, 23 pp 152-173

KIRBY D A (1992) Chapter 5 in Howe S 1992 Retailing Management Macmillan:

Basingstoke UK

KOREA CHAIN STORES ASSOCIATION (2011) Statistics KCSA, Seoul; Korea.

KOREA JOONGANG DAILY, (2013a) Mandatory closures may be working (May 09, 2013).

KOREA JOONGANG DAILY (2013b) After a year of regulation, some cooperation, http://koreajoongangdaily.joins.com/news/article/Article.aspx?aid=2970542(Apr 23, 2013).

KOREA STATISTICS homepage, (2011)

http://kostat.go.kr/portal/korea/index.action)

MILLER D (1998). A Theory of Shopping. Cambridge: Polity Press

NEW AMERICA FOUNDATION (2012) Out of Business A report by New America Foundation July 2012

OECD (2001), Regulatory Reform in Retail Distribution, OECD Economic Studies $32,2001 / 1$

RAM M and SHETH, J. N. (1989). Consumer resistance to innovations: the marketing problem and its solutions. Journal of Consumer Marketing 6, 5-14.

RAMSTAD E. (2006). Wal-Mart Leaves South Korea By Selling Stores to Local Rival; Sale to Shinsegae Follows April Pullout by Carrefour As Domestic Firms Prevail Wall Street Journal. (Eastern Edition). New York, N.Y.: May 23, 2006. p. A.2

RICHTER P (1994), Seven Days' Trading Make One Week? The Sunday Trading Issues as an Index of Secularization, The British Journal of Sociology, 45 pp. 333348.

RYLE S (2013) The making of TESCO. London: Bantam Press. 
SERPKENCI R and TIGERT D (2010) Antecedents and consequences of structural change in North American retailing 1990-2010 International Review of Retail, Distribution and consumer research 20 pp. 29-68

SMBA (2010, 2011) Retail Store Statistics. Small and Medium Business Administration. Seoul, South Korea

SMBA (2012) Press Release on mandatory store closures. Small and Medium Business Administration. Seoul, South Korea

SPARKS L (2008) Commentary: when Tony met Bobby. Environment and Planning A 40 pp 2793-2799

STERNQUIST B (1998) International retailing New York: Fairchild

SUH Y-G and HOWARD E (2009) Restructuring retailing in Korea: the Case of Samsung-Tesco. Asia Pacific Business Review 15 pp 29-40

TESCO (2013) Tesco PLC Annual Report and Financial Statement 2013 (http://www.tescoplc.com/index.asp?pageid=540)

TESCO website, (2013) (http://www.tesco.com)

THE DAILY TELEGRAPH (2012), Tesco profits fall for first time in 18 years (http://www.telegraph.co.uk/finance/newsbysector/retailandconsumer/9583264/Te sco-profits-fall-for-first-time-in-18-years.html)

THE KOREA TIMES (2012) Discount Stores Face Obligatory Shutdowns on Sundays,

Holiday (http://koreatimes.co.kr/www/news/nation/2012/03/113_107324.html) (20 Mar, 2012),

THE KOREA TIMES (2013) Homeplus CEO to step down. (http://www.koreatimes.co.kr/www/news/nation/2013/07/116_130792.html) (19 February, 2013),

TIMMERMANS, HJP (1979) A spatial preference model of regional shopping behaviour. Tijdschrift voor Economische en Sociale Geografie 70 pp.309-312. 